\title{
Bienaventurados los ateos porque encontrarán a Dios
}

Blessed are the atheists for they will find God

Los dogmas del Catolicismo, la religión en la que nací, ya no me dicen nada. Las tradiciones y creencias del Cristianismo, tal como las aprendí, me parecen cada vez más ajenas. Son respuestas. Y ante el misterio del mundo yo tengo cada vez más preguntas.

Sentimientos parecidos a los míos los descubro en mucha otra gente, sobre todo jóvenes, sobre todo mujeres, que no niegan a Dios, pero que buscan una espiritualidad que alimente de verdad el sentido de sus vidas. $\mathrm{Y}$ en busca de ese tesoro, donde poner su corazón, toman distancia, se apartan, revisan, hasta rechazan, la religión aprendida.

¿Qué nos pasa? ¿Qué me ha pasado? Que he crecido, que he leído, que he buscado, que vivimos en un mundo radicalmente diferente al mundo tribal, rural, pre-moderno, en el que se fraguaron los ritos, dogmas, creencias, jerarquías y tradiciones de mi religión. El sistema religioso que nos han enseñado habla de un concepto anticuado del mundo. Ya no podemos caminar con esos "zapatos", ya no me sirven.

\footnotetext{
Paper-Comunicación recibido el 21 Agosto de 2014 y aprobado el 17 de marzo de 2015.

* Periodista y escritora. Redactora Jefa de la Revista Envío, de la Universidad Centroamericana (UCA). País de origen: Nicaragua. E-mail: maria@untaljesus.net
} 
Sabiendo, como sé, que el Cristianismo en todas sus versiones (católicos, protestantes, evangélicos, ortodoxos...) es una religión poderosa, pero una más entre tantas que existen y han existido en el planeta y en la historia, ya no puedo creer que la mía es la religión verdadera. Sería una insensatez tan mayúscula como creer que mi lengua materna, el español, es entre todas las lenguas, la mejor sólo porque nací en ella, es la que conozco y la que sé hablar.

Encuentro arrogantes los postulados religiosos que aprendí. Porque se presentan absolutos, rígidos, infalibles, incuestionables, inmutables e impenetrables al paso del tiempo. Y la humildad -que tiene la misma raíz, que humanidad, humus - me parece un caminito esencial ante el misterio del mundo, que ni la ciencia ni ninguna religión logra desentrañar cabalmente.

Sabiendo, como sé, las riquezas que encierran las variadísimas culturas humanas, los tantos mundos que hay en este mundo, no puedo creer que en mi religión y en la Biblia esté "la” revelación de esa Realidad Última que es Dios. Si así lo creyera, no podría evitar ser soberbia. Y no podría dialogar de igual a igual con los miles y miles y miles de hombres y mujeres que no lo creen así, que tienen otros libros sagrados, que van a Dios por otros caminos en donde no hay escrituras santas que venerar y seguir.

¿Cómo creer en ese galimatías dogmático, amalgamado con una filosofía superada, que afirma que en Dios hay tres personas distintas con una única naturaleza y que Jesús es la segunda persona de esas tres, pero con dos naturalezas? ¿Cómo creer lo que es absurdo y no entiendo si mi cerebro es la obra maestra de la Vida? ¿Cómo creer que María de Nazaret es Madre de Dios si Dios es Madre? ¿Cómo creer en la virginidad de María sin asumir lo que ese dogma expresa de rechazo a la sexualidad y a la sexualidad de las mujeres? ¿Cómo aceptar una religión tan masculinizada $y$, por tanto, tan separada de aquella primera intuición que presentía a Dios en femenino al ver el poder del cuerpo de la mujer que daba vida? ¿Cómo olvidarnos de que, por esa experiencia vital, Dios “nació mujer” en la mente de la humanidad? 
¿Cómo creer en el infierno sin convertir a Dios en un tirano torturador como los Pinochet o los Somoza? ¿Cómo creer en el pecado original, que nunca nadie cometió en ningún lugar, que es solamente el mito con que el pueblo hebreo explicó el origen del mal en el mundo? ¿Cómo creer que Jesús nos salvó de ese pecado si esa doctrina no es de Jesús de Nazaret sino de Pablo de Tarso? ¿Cómo creer que Dios necesitaba de la muerte de Jesús para lavar ese pecado? Jesús el profeta, ¿un cordero propiciatorio que aplaca con sangre la cólera divina? ¿Cómo creer que Jesús nos salvó muriendo, cuando lo que nos puede "salvar" del sinsentido es que nos enseñó a vivir? ¿Cómo creer que como el cuerpo de Jesús y bebo su sangre, reduciendo así la Eucaristía a un rito materialista, mágico y evocador de sacrificios arcaicos y sangrientos que Jesús rechazó?

Sin embargo, dejando ya en mi camino tantas creencias de la religión aprendida, no dejo a Jesús de Nazaret. Porque, así como mi padre, mi madre y mis hermanos son mis referentes afectivos, y así como pienso, hablo y escribo en español y esa lengua es mi referente cultural, Jesús de Nazaret es mi referente religioso y espiritual, mi referente ético, el que me es más familiar para tantear el camino que me abre al misterio del mundo.

Hoy, sabiendo, como sé, de la majestad inabarcable del Universo en el que vivimos, con sus miles de millones de galaxias, no puedo creer que Jesús de Nazaret sea la única y definitiva encarnación de esa Energía Primera que es Dios. Eso no lo creyó Jesús. Esa elaboración dogmática, hecha posteriormente y en contextos de luchas de poder, escandalizaría a Jesús. Hoy, en vez de afirmar “creo que Jesús es Dios”, prefiero decirme y decir: “Quiero creer en Dios como creyó Jesús”.

¿Y en qué Dios creía Jesús, el Moreno de Nazaret? Nos enseñó que Dios es un padre, también una madre, que se preocupa por buscarnos, -el pastor que busca a su oveja, la mujer que busca su dracma-, que nos espera con ansia, que siempre acoge, que se indigna ante las injusticias y ante el poder que explota y oprime, que toma partido por los de abajo, que no quiere pobres ni ricos, que quiere que a nadie 
le sobre y a nadie le falte, que apuesta por la equidad y la dignidad de todos, que nos quiere hermanos, que nos quiere en comunidad, que no quiere señores ni siervos, tampoco siervas, que nos da siempre oportunidades, que se ríe y festeja, que celebra banquetes a los que invita a todos, que es alegre y es bueno, que es un abbá, una immá.

Todas las religiones del mundo, toditas, se parecen en algo: todas afirman que son las verdaderas y se ufanan de que sus divinidades son las más poderosas. Todas se sostienen en creencias, en ritos, en mandamientos y en mediadores. La mayoría de los mandamientos que imponen son prohibiciones: lo que no se puede hacer, lo que no se puede pensar, lo que no se puede decir... Y los mediadores que dominan las religiones son variadísimos: son libros, lugares, tiempos y objetos sagrados y, sobre todo, son personas sagradas a las que hay que creer, obedecer y reverenciar.

Cuando uno lee la buena noticia de los Evangelios, cuando capta su esencia, descubre que Jesús no fue un hombre religioso. Jesús fue un laico en contradicción permanente con los hombres piadosos y sagrados de su tiempo, fariseos y sacerdotes. Jesús no propuso creencias sino actitudes. No lo vemos nunca practicando ningún rito sino acercándose a la gente. Le dio la vuelta a varios mandamientos, tal como eran interpretados por los piadosos de su tiempo. Y no respetó ni los lugares sagrados (oraba en el monte) ni los tiempos sagrados ("El sábado es para la gente, no la gente para el sábado”).

Jesús fue un hombre espiritual y un maestro ético. Jesús no quiso fundar ninguna religión y, por eso, no es responsable de ninguno de los dogmas construidos desde el poder sobre la memoria apasionada de quienes lo conocieron. Jesús propuso una ética de relaciones humanas. Inspiró un movimiento espiritual y social de hombres y mujeres que buscando a Dios buscaran la justicia y construyeran su sueño, el Reino de Dios, que él concibió como una utopía contrapuesta a la realidad de opresión, injusticia, que le tocó vivir en su país y en su tiempo. 
Cuando ninguna persona es sagrada todas las personas se vuelven sagradas. Cuando ningún objeto es sagrado todos los objetos merecen ser cuidados. Cuando ningún tiempo es sagrado todos los días que me es dado vivir se convierten en sagrados. Cuando ningún lugar es sagrado veo en la Naturaleza entera el sagrado templo de Dios. Esto también nos lo enseñó Jesús.

La irreverencia, la provocación, la gracia, el humor, la audacia y la novedad de la espiritualidad de Jesús de Nazaret han sido aprisionadas desde hace siglos en la dogmática cristológica. Esa dogmática nos hace prisioneros de un pensamiento único, nos encierra en una jaula. No nos deja volar porque no nos deja preguntar, sospechar, dudar... Los barrotes de esa cárcel provocan miedo. Miedo a desobedecer la palabra autorizada de quienes "saben de Dios", las jerarquías de la religión. Miedo a ser castigados por pensar y por decir lo que pensamos.

Hoy, sabiendo que vivo "en torno a una estrella del montón, en una zona corriente de una galaxia vulgar, agrupada con otras igualmente anodinas en un cúmulo ordinario", como describe este "barrio cósmico" que es la Tierra un prestigioso físico, no puedo dejar de sentir petulantes y esclerotizadas, irrelevantes para mi vida, las certezas y las normas de la religión organizada por una burocracia jerárquica que, además, en tantas cosas ha traicionado el mensaje de Jesús.

Me encuentro más cercana a la Vida que Jesús defendió y dignificó en esa religiosidad, en esa espiritualidad que es reverencia y asombro ante el misterio del mundo. Hallo más sentido espiritual en la "religiosidad cósmica" de la que habló el judío Einstein cuando dijo: "El misterio es lo más hermoso que nos es dado sentir". Einstein reconoce que esa experiencia de lo misterioso "cuna del arte y de la ciencia ha generado también la religión”. Pero añade: “La verdadera religiosidad es saber de esa Existencia impenetrable para nosotros, saber que hay manifestaciones de la Razón más profunda y de la Belleza más resplandeciente” que nunca nos son del todo asequibles. Y concluye: "A mí me basta con el misterio de la eternidad de la Vida, con el presentimiento y la conciencia de la construcción prodigiosa de lo existente". 
No sé si a mí me basta esa formulación, pero sí sé que me resulta significativa porque me abre a nuevas preguntas. Y la religión, el sistema religioso en el que me educaron, no me abrió. Me cerró llenándome de respuestas fijas, preestablecidas, muchas de ellas amenazantes, angustiantes, generadoras de miedo, de culpa y de infelicidad. Es tiempo de humanizarnos. Y el sistema religioso, obligándonos a pensar a Dios de una única manera, imponiéndonos normas morales severas y faltas de compasión y obligándonos a cultos y ritos rutinarios y rígidos, nos deshumaniza.

¿Creo en Dios? ¿Qué es la fe? “Es un amor”, me respondió hace ya muchos años un campesino analfabeto en la República Dominicana cuando yo se lo pregunté. Nunca lo olvido. Sentí una explicación tan sencilla como profunda.

Si Dios es, es quien me mueve siempre hacia el amor, hacia los demás, sean personas, animales, árboles... Ese movimiento, ese impulso es a compartir, a simpatizar, a cuidar, a hacerme responsable, a meterme en el agua que guarda en su fondo ese pozo de todo lo que está vivo. La amistad es la felicidad de no poder tocar nunca el fondo de ese pozo. Eso es amor: un pozo sin fondo en el que poder beber. Eso debe ser Dios. En el amor que tengo a quienes quiero yo siento a Dios.

Si Dios es, es belleza. El derroche de belleza de la Naturaleza -las estrellas del cielo, los ojos de los perros, la forma de las hojas, el vuelo de los pájaros, los colores y sus matices, el mar-, todo ese inconmensurable y siempre sorprendente listado de hermosuras, todas parecidas, todas diferentes, todas relacionadas, esa belleza que yo no puedo ni abarcar ni entender, que deslumbra mis ojos y mi mente, que la ciencia nos descubre y nos explica, siento que tiene "la firma" de Dios. En el fondo de toda la belleza que veo en todo lo que existe yo siento a Dios.

Si Dios es, es alegría. En la fiesta, en la música y el baile, en las formas indefinibles que adopta la alegría cuando es profunda, en la palabra, en la compañía, en la celebración, en los logros, en el esfuerzo de creatividad, y muy 
especialmente en las risas y en las sonrisas de la gente, yo siento que Dios es más cercano que nunca.

Si Dios es, es también justicia. Es la justicia que la historia que conozco y en la que vivo no le ha garantizado nunca a la gente buena. Que no le garantizó a aquel campesino pobre y analfabeto que me definió la fe como "un amor”.

Pero Dios siempre está más allá de todo amor, de toda belleza, de toda alegría, siempre inalcanzable, innombrable, indescifrable, siempre más allá de la idea que de Dios me hago, más allá de mi propio deseo y nostalgia. Maimónides, el gran pensador judío de la Edad Media, escribió un tratado teológico-filosófico con este fascinante título: "Guía para perplejos". Dice él: "Describir a Dios mediante negaciones es la única manera de describirlo en un lenguaje apropiado".

Ni una pizca de esa perplejidad la encuentro ya en el sistema religioso en el que nací. Y es con estos "ladrillos" de pensamiento y de sentimiento, con este pensar y este sentir, con los que he ido construyendo a tientas una espiritualidad, convencida, como decía el poeta León Felipe, que nadie va a Dios por el mismo camino por el que voy yo. La espiritualidad es un camino personal, la religión es un corsé colectivo. Un “yugo pesado”, en palabras de Jesús.

En su libro La ola es el mar, el monje benedictino Willigis Jäger comenta: “Una persona sagaz dijo: La religión es un truco de los genes”. Jäger se toma muy en serio esa afirmación. Y explica: “Cuando la especie humana alcanzó el nivel evolutivo adecuado para plantearse preguntas sobre su origen, su futuro y el sentido de su existencia, desarrolló la capacidad para dar respuesta a esas preguntas. El resultado de este proceso es la religión, que durante milenios ha desempeñado magníficamente su tarea y aún sigue haciéndolo hoy. La religión forma parte de la evolución humana. Y si hoy llegamos a un punto en que sus respuestas ya no satisfacen, es un indicio de que la evolución ha dado un paso hacia adelante y está surgiendo en la humanidad una nueva capacidad para comprendernos como seres humanos”. 
A pesar de los caminos errados y de los tiempos perdidos, cuánto me alegro de que, antes de morirme, desarrollé esa capacidad y pude vivir en el tiempo de ese paso hacia adelante. 